\title{
Bioactive Constituents and In vitro Antioxidant Capacity of Water Leaf (Talinum triangulare) as Affected by Domestic Cooking
}

\author{
Eleazu Chinedum Ogbonnaya ${ }^{{ }^{*}}$ and Eleazu Kate Chinedum ${ }^{2}$ \\ ${ }^{1}$ Department of Biochemistry, National Root Crops Research Institute, Umudike, Nigeria. \\ ${ }^{2}$ Department of Biochemistry, Michael Okpara University of Agriculture, Umudike, Nigeria. \\ Authors' contributions \\ This work was carried out in collaboration between all authors. Author ECO and EKC \\ designed the study, performed the statistical analysis, wrote the protocol, and wrote the first \\ draft of the manuscript. Author ECO analyzed the data generated. Author EKC did the \\ literature searches.All authors read and approved the final manuscript.
}

\section{ABSTRACT}

Background and Aim: Despite the pharmacological relevance of Water leaf (Talinum triangulare), there is paucity of information in literature on the effect of boiling on its pharmacopotency as well as nutritional properties.

Methodology: The total chlorophyll, carotenoids, proximates, phytochemicals, minerals, vitamins and antioxidant assays of the leaves of the vegetable were performed using standard techniques.

Results: The raw leaves of water leaf (Talinum triangulare) possessed considerable amounts of proximates, phytochemicals, minerals, vitamins, chlorophyll as well as antioxidant activity but had low levels of carbohydrates and energy value. Cooking of the raw leaves of the vegetable for 5 minutes resulted in insignificant $(P>0.05)$ losses of proximates, phytochemicals, $\mathrm{Ca}, \mathrm{Fe}, \mathrm{Zn}$, thiamin, riboflavin, niacin and tocopherol, but significant $(\mathrm{P}<0.05)$ losses of vitamin $\mathrm{C}$, carotenoids, $\mathrm{Mg}, \mathrm{P}$, chlorophyll and antioxidant activity with a corresponding increase in moisture, proteins and crude fibre contents. Conclusion: The conventional method of cooking of the raw waterleaf in Nigeria leads to an increase in its protein and crude fibre contents which justifies the usage of the cooked vegetable in the management of obesity, stroke and diabetes mellitus in Nigeria. 
Keywords: Talinum triangulare; cooking; raw leaves; bioactive constituents; antioxidant capacity.

\section{STATEMENT OF AUTHORSHIP}

Eleazu Chinedum Ogbonnaya and Eleazu Kate Chinedum designed the study. Eleazu Chinedum Ogbonnaya wrote the manuscript and carried out statistical analysis of the results. Eleazu Kate Chinedum read the manuscript and corrected the typographical errors.

\section{INTRODUCTION}

In tropical Africa where the daily diet is dominated by starchy staples, African indigenous leafy vegetables are the most readily available sources of important micro-nutrients such as: vitamins, especially the pro-vitamin A or $\beta$-carotene [1] as well as essential amino acids and mineral elements. These vegetables are important commodities for poor households because their prices are relatively affordable compared with other food items.

Water leaf (Talinum triangulare) is a herbaceous perennial plant that is widely grown in tropical regions as a leafy vegetable and it belongs to the family of Portulaceae [2]. In Nigeria, it is used in the preparations of 'Afang', Edikaiko and 'Gbure' soups which are indigenous to the Efiks, Ibibios and Yorubas, respectively. Water leaf is a rich source of vitamins, $\beta$-carotene, minerals (such as calcium, potassium and magnesium), pectin, proteins and vitamins [2].

It has also been found to possess useful medical potentials such as laxative, purgative, treatment of diarrhea, gastro-intestinal diseases $[3,4]$ as well as in the management of cardiovascular diseases such as: stroke and obesity [5].

However, despite the widely reported pharmacological relevance of Talinum triangulare, there is dearth of information on the effect of boiling on the pharmacopotency and the nutritional properties of the vegetable.

In addition, with the recent wind of economic depression and its resultant effect on the purchasing power of commodities for people living in less developed nations, it has become obvious that the local food stuffs and vegetables which prices are easily affordable, will play increasing roles in the food, nutrition and health security of the impoverished people living in the rural areas. Therefore, this research was setout to determine the effect of boiling on the bioactive constituents and antioxidant capacity of the leaves of Talinum triangulare.

\section{MATERIALS AND METHODS}

Fresh samples of Water leaf (Talinum triangulare) were bought from Umuahia main market, Abia State, Nigeria and transported to our Laboratory for processing and analysis within 10 min. The leaves were properly washed before being then chopped into homogeneous pieces. Some samples of the vegetable were taken to the Department of Botany, Michael Okpara University of Agriculture, Umudike, Nigeria where they were identified and authenticated. DPPH (2,2-diphenyl-1-picrylhydrazyl), standard tocopherol and quercetin that were used, were products of Sigma and Aldrich Chemical Company (UK) and were of analytical grade. Every other chemical that was used, was bought from Hoslab, Umuahia and was of analytical grade. 


\subsection{Sample Treatments}

Exactly $200 \mathrm{~g}$ of the homogeneous pieces of water leaf were immersed in a well covered beaker, containing $500 \mathrm{ml}$ of boiling water. The leaves were removed after 5 minutes of boiling.

\subsection{Analytical Procedure}

\subsubsection{Chlorophyll determination}

The water leaf sample $(0.5 \mathrm{~g})$ was grinded to slurry and extracted in $10 \mathrm{ml}$ of $80 \%(\mathrm{v} / \mathrm{v})$ acetone after 30 seconds of grinding. The extract was centrifuged at $1500 \times \mathrm{g}$ for $10 \mathrm{~min}$ at room temperature and the residue was removed. The total chlorophyll content was determined by recording the absorbance at 645 and $663 \mathrm{~nm}$ with a UV spectrophotometer (Genesys 10 VIS Thermo Electron Corporation) against the reagent blank that contained $80 \%$ acetone. The total chlorophyll content of the sample was calculated as the sum of chlorophyll $\mathrm{a}$ and chlorophyll $\mathrm{b}$ where chlorophyll $\mathrm{a}=12.7 \times$ Absorbance $663^{-} 2.69 \mathrm{x}$ Absorbance 645 and chlorophyll b $=22.9 \times$ Absorbance $645-4.68 \times$ Absorbance 663 and results were expressed as $\mathrm{mg} / \mathrm{g}$ fresh weight [6].

\subsubsection{Total carotenoid determination}

The carotenoid content of the fresh and cooked samples was determined using the method of Rodriquez-Amaya and Kimura [7] and results were expressed as $\mu \mathrm{g} / \mathrm{g}$ on fresh weight basis.

\subsubsection{Cyanide assay}

The cyanogenic glucoside contents of the fresh and cooked samples were determined using the alkaline picrate method [8].

\subsubsection{Rapid TLC free radical scavenging screening}

The modified method of Mensor et al.[4] was used in screening for the antioxidant property of the extracts of the raw and cooked leaves of Talinum triangulare. With the aid of capillary tube, stock solutions $(100 \mathrm{mg} / \mathrm{ml}$ ) (instead of $1 \mathrm{mg} / \mathrm{ml}$ ) of the methanolic extracts were spotted on silica gel thin layer chromatographic (TLC) plate and developed with a solvent system of ethanol: methanol (50:50) instead of (90: 10). After development, the chromatograms were dried and sprayed with a $0.3 \mathrm{mM}$ solution of the stable DPPH free radical. The plates were visualized for the presence of yellow spots and the degree of activity was determined qualitatively from the observation of the yellow colour intensity. Quercetin was used as the positive control for this assay.

\subsubsection{2,2-Diphenyl-1- picrylhydrazyl (DPPH) radical scavenging assay}

The method of Blois [9] was used with modifications. A measured amount $(5 \mathrm{~g})$ of each sample (raw and cooked) was dissolved in $100 \mathrm{ml}$ of methanol to give a concentration of $50 \mathrm{mg} / \mathrm{ml}$ and the mixture was filtered with Whatmann No 1 Filter Paper through vacuum pump (Model 2037 Gardner Denver). Then, $0.1,0.2,0.3,0.4$ and $0.5 \mathrm{ml}$ of each filtrate was diluted with methanol to give final concentrations of $62.5,125,187.5,250$ and $312.5 \mu \mathrm{g} / \mathrm{ml}$ respectively. Finally, $0.1 \mathrm{ml}$ of $0.3 \mathrm{mM}$ DPPH in methanol was added to each of the reaction mixtures and the whole setup was well shaken and left in the dark for 
30 mins before the absorbance was read spectrophotometrically at $517 \mathrm{~nm}$ against the DPPH control that contained $1 \mathrm{ml}$ of methanol only in place of the extract. The same procedure was followed for standard quercetin $(2.5 \mathrm{mg} / \mathrm{ml}$ in methanol) which was diluted to $62.5,125,187.5,250$ and $312.5 \mu \mathrm{g} / \mathrm{ml}$ respectively. The radical scavenging activity was calculated as: \% Scavenging activity=[(Absorbance of control - Absorbance of sample)/Absorbance of control] $\times 100$.

\subsubsection{Mineral assay}

The Atomic Absorption Spectrophotometer (Analyst 200, Perkin Elmer, Waltham, MA, USA) was used in the analysis of $\mathrm{Fe}, \mathrm{Mg}$ and $\mathrm{Ca}$ while the molybdate method [8] was used in the analysis of the phosphorous content of the raw and cooked leaves of the vegetable.

\subsubsection{Proximate analysis}

The proximate composition analysis of the raw and cooked leaves of the vegetable was determined using the AOAC methods [10].

\subsubsection{Phytochemical analysis}

The gravimetric method of Harbone [11] was used in the determination of the total alkaloid content while the AOAC method [10] was used in the determination of the saponins, tannins and flavonoid contents of the raw and cooked leaves of the vegetable.

\subsubsection{Determination of water soluble vitamins}

The riboflavin, thiamin and niacin contents of the raw and cooked leaves of Talinum triangulare were determined using the method of Okwu and Josiah[12]. The vitamin C contents of the raw and cooked leaves of the vegetable were determined using the titrimetric method [8].

\subsubsection{Determination of tocopherol (Vitamin E)}

The tocopherol content of the raw and cooked leaves of the vegetable was determined using the method of Tsen [13] and results were expressed as $\mathrm{mg} / 100 \mathrm{~g}$ on fresh weight basis.

\subsection{Statistical Analysis}

Results are reported as the means \pm standard deviations of triplicate experiments. Student $t$-test was used for statistical comparison while one way analysis of variance was used for statistical analysis of DPPH antioxidant assays. Results were considered to be significant at $P<.05$.

\section{RESULTS}

\subsection{Proximate Composition}

The percentage decrease in ash, carbohydrates, lipids and energy values in the cooked leaves of Talinum triangulare were $12.57 \%, 29.20 \%, 5.26 \%$ and $1.01 \%$ respectively while $8.0 \%, 28.7 \%$ and $0.49 \%$ increases were observed in crude fibre, protein and moisture contents of the cooked vegetable, respectively (Table 1). There were no significant differences in the proximate composition of the raw and cooked leaves of the vegetable $(P>0.05)$. 
Table 1. Proximate composition of raw and cooked water leaf

\begin{tabular}{|c|c|c|c|c|c|c|c|}
\hline & $\begin{array}{l}\text { Moisture } \\
\text { (\%) }\end{array}$ & Ash (\%) & CF (\%) & Lipid (\%) & CP (\%) & $\mathrm{CHO}(\%)$ & $\mathrm{EV}(\mathrm{Kcal} / 100 \mathrm{~g})$ \\
\hline Raw & $89.82 \pm 0.11$ & $1.75 \pm 0.01$ & $3.25 \pm 0.01$ & $1.14 \pm 0.01$ & $3.24 \pm 0.00$ & $4.11 \pm 0.13$ & $39.48 \pm 0.10$ \\
\hline $\begin{array}{l}\text { Cooke } \\
\text { d }\end{array}$ & $90.26 \pm 0.21^{a}$ & $1.53 \pm 0.05^{a}$ & $3.51 \pm 0.04^{a}$ & $1.08 \pm 0.00^{a}$ & $\begin{array}{l}4.17 \pm 0.01 \\
\mathrm{a}\end{array}$ & $2.91 \pm 0.11^{a}$ & $39.08 \pm 0.76^{a}$ \\
\hline
\end{tabular}

\subsection{Phytochemical Composition}

Cooking of the leaves of Talinum triangulare resulted in $15.38 \%$ loss of tannins, $24.39 \%$ loss of alkaloids, $39.39 \%$ loss of flavonoids, $12 \%$ loss of sterols, $15.91 \%$ loss of cyanogenic glycosides and $31.17 \%$ loss of saponins respectively (Table 2). Results obtained showed that there were no significant differences in the phytochemical contents of the raw and cooked leaves of the vegetable $(P>0.05)$.

Table 2. Phytochemical composition of raw and cooked water leaf

\begin{tabular}{lllllll}
\hline & $\begin{array}{l}\text { Tannin } \\
(\mathbf{\%})\end{array}$ & $\begin{array}{l}\text { Alkaloid } \\
(\mathbf{\%})\end{array}$ & $\begin{array}{l}\text { Flavonoid } \\
(\mathbf{\%})\end{array}$ & Sterol (\%) & $\begin{array}{l}\text { HCN } \\
(\mathbf{M g} / \mathbf{k g})\end{array}$ & $\begin{array}{l}\text { Saponin } \\
(\%)\end{array}$ \\
\hline Raw & $0.65 \pm 0.00$ & $0.41 \pm 0.01$ & $0.33 \pm 0.01$ & $0.05 \pm 0.01$ & $0.44 \pm 0.05$ & $0.77 \pm 0.02$ \\
Cooked & $0.55 \pm 0.01^{\mathrm{a}}$ & $0.31 \pm 0.00^{\mathrm{a}}$ & $0.20 \pm 0.01^{\mathrm{a}}$ & $0.044 \pm 0.00^{\mathrm{a}}$ & $0.37 \pm 0.02^{\mathrm{a}}$ & $0.53 \pm 0.01^{\mathrm{a}}$ \\
\hline Values are the means \pm standard deviations of triplicate experiments. ${ }^{\mathrm{a}} \mathrm{P}>0.05$ & in comparison with raw. HCN- \\
Cyanide
\end{tabular}

\subsection{Vitamin and Carotenoid Composition}

About $33.33 \%$ loss of thiamin, $17.65 \%$ loss of riboflavin, $17.78 \%$ loss of niacin, $4.80 \%$ loss of tocopherols, $15.69 \%$ loss of ascorbic acid and $13.19 \%$ loss of carotenoids respectively were recorded in cooked leaves of the vegetable (Table 3 ).

Table 3. Vitamin composition of raw and cooked water leaf

\begin{tabular}{cllllll}
\hline & $\begin{array}{l}\text { Thiamin } \\
(\mathbf{m g} / \mathbf{1 0 0})\end{array}$ & $\begin{array}{l}\text { Riboflavin } \\
(\mathbf{m g} / \mathbf{1 0 0})\end{array}$ & $\begin{array}{l}\text { Niacin } \\
(\mathbf{m g} / \mathbf{1 0 0})\end{array}$ & $\begin{array}{l}\text { Tocopherol } \\
(\mathbf{m g} / \mathbf{1 0 0 g})\end{array}$ & $\begin{array}{l}\text { Vitamin C } \\
(\mathbf{m g} / \mathbf{1 0 0})\end{array}$ & $\begin{array}{l}\text { Carotenoids } \\
(\boldsymbol{\mu g} / \mathbf{g})\end{array}$ \\
\hline Raw & $0.03 \pm 0.00$ & $0.17 \pm 0.01$ & $0.45 \pm 0.02$ & $22.71 \pm 0.13$ & $48.95 \pm 0.30$ & $264.57 \pm 0.33$ \\
Cooked & $0.02 \pm 0.00$ & $0.14 \pm 0.01$ & $0.37 \pm 0.01$ & $21.62 \pm 0.03$ & $41.27 \pm 0.04^{*}$ & $229.66 \pm 0.06^{*}$ \\
\hline \multicolumn{6}{c}{ Each value in the table is the average of triplicate experiments \pm std. } \\
& ${ }^{*} P<0.05$ in comparison with raw \\
within the group (column). &
\end{tabular}

\subsection{Mineral Composition}

Analysis of the mineral contents of the vegetable indicated that the raw sample had the mean value of $83.18 \pm 0.39 \% \mathrm{Ca}, 75.87 \pm 0.04 \% \mathrm{Mg}, 124.96 \pm 0.28 \% \mathrm{P}, 3.77 \pm 0.11 \% \mathrm{Fe}$ and $1.52 \pm 0.04 \% \mathrm{Zn}$ while the cooked samples had $76.65 \pm 0.30 \% \mathrm{Ca}, 64.62 \pm 0.45 \% \mathrm{Mg}$, $116.8 \pm 0.40 \% \mathrm{P}, 3.2 \pm 0.16 \% \mathrm{Fe}$ and $1.37 \pm 0.03 \% \mathrm{Zn}$. Cooking of the raw vegetable resulted in $7.85 \%$ loss of $\mathrm{Ca}, 14.83 \%$ loss of $\mathrm{Mg}, 6.53 \%$ loss of $\mathrm{P}, 12.73 \%$ loss of $\mathrm{Fe}$ and $9.87 \%$ loss of Zn (Table 4). 
Table 4. Mineral composition of raw and cooked water leaf $(\mathrm{mg} / 100 \mathrm{~g})$

\begin{tabular}{llllll}
\hline & $\mathbf{C a}$ & $\mathbf{M g}$ & $\mathbf{P}$ & $\mathbf{F e}$ & $\mathbf{Z n}$ \\
\hline Raw & $83.18 \pm 0.39$ & $75.87 \pm 0.04$ & $124.96 \pm 0.28$ & $3.77 \pm 0.11$ & $1.52 \pm 0.04$ \\
Cooked & $76.65 \pm 0.30$ & $64.62 \pm 0.45^{*}$ & $116.80 \pm 0.40^{*}$ & $3.29 \pm 0.16$ & $1.37 \pm 0.03$ \\
\hline \multicolumn{4}{c}{ Values are expressed as means + standard deviations of triplicate experiments; ${ }^{*} P<0.05$ in } \\
comparison with raw within the group (column).
\end{tabular}

\subsection{Antioxidant Assay}

The thin layer chromatographic screening of the methanolic and ethanolic extracts of the raw and cooked vegetable indicated that both possessed varying levels of antioxidant capacity with that of the raw sample being stronger and close to that of standard quercetin (Table 5).

Table 5. Radical scavenging activities of the methanolic/ethanolic extracts of raw and cooked water leaf using rapid DPPH TLC screening

\begin{tabular}{|c|c|c|}
\hline Sample & Reaction speed & Intensity of spots \\
\hline Raw & Fast & +++ \\
\hline Cooked & Slow & ++ \\
\hline Quercetin & Fast & +++ \\
\hline
\end{tabular}

Analysis of the free radical scavenging activities of the methanolic extracts of the raw and cooked samples Talinum triangulare on 2,2 diphenyl-1-picrylhydrazyl radical indicated that the raw vegetable had a mean scavenging activity of $74.32 \pm 8.67 \%$ with an $\mathrm{IC}_{50}$ of $27.55 \mu \mathrm{g} / \mathrm{ml}$ comparable to that of standard quercetin that had a percentage scavenging activity of $78.27 \pm 9.07 \%$ with an $I_{50}$ of $22.77 \mu \mathrm{g} / \mathrm{ml}$ while the cooked vegetable had a mean scavenging activity of $56.43 \pm 26.82$ with an $\mathrm{IC}_{50}$ of $139.31 \mu \mathrm{g} / \mathrm{ml}$ (Table 6).

Table 6. Free radical scavenging activities of raw and cooked water leaf

\begin{tabular}{lll}
\hline Sample & $\begin{array}{l}\text { Mean scavenging } \\
\text { activity }(\%)\end{array}$ & $\mathbf{I C}_{\mathbf{5 0}}(\boldsymbol{\mu g} / \mathbf{m l})$ \\
\hline Raw & $74.32 \pm 8.67$ & 27.55 \\
Cooked & $56.43 \pm 26.82^{\mathrm{b}}$ & $139.31^{\mathrm{c}}$ \\
Quercetin & $78.27 \pm 9.07^{\mathrm{a}}$ & $22.77^{\mathrm{a}}$ \\
\hline Linear equation for raw: $Y=31.48 x+4.666\left(R^{2}=0.983\right) ;(2)$ & Linear equation for cooked: $Y=95.01 x-$ \\
153.7 $\left(R^{2}=0.935\right) ;(3)$ Linear equation for quercetin: $Y=33.07 x+5.114\left(R^{2}=0.989\right) .{ }^{a} P<0.05$ in \\
comparison with cooked; ${ }^{b} P>0.05$ in comparison with raw; ${ }^{c} P<0.05$ in comparison with raw.
\end{tabular}

The mean value of the total chlorophyll content of the raw vegetable was $5.09 \pm 0.01 \mathrm{mg} / \mathrm{g} \mathrm{fw}$ (fresh weight) while that of the cooked sample was $2.31 \pm 0.02 \mathrm{mg} / \mathrm{g} \mathrm{fw}$. In addition, we recorded a $54.62 \%$ loss of chlorophyll when the raw vegetable was cooked (Fig. 1). 


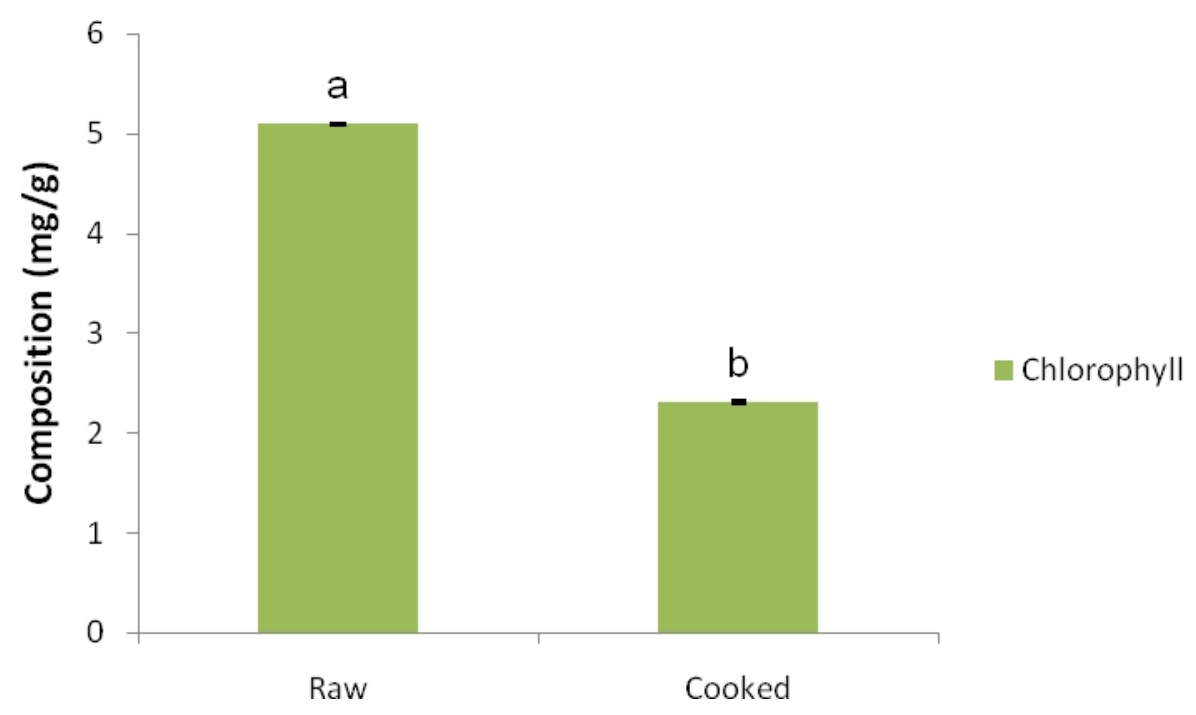

Fig. 1. Chlorophyll contents of raw and cooked Talinum triangulare ${ }_{a-b} P<.05$ (Significantly different from each other)

\section{DISCUSSION}

The cooking method used in this study reflects the major way in which water leaf is being consumed in a typical African diet.

The increase in the moisture content of the leaves of Talinum triangulare after cooking was expected as cooking in water tends to soften the cell wall of the vegetable. In addition, more water may have entered the vegetable by osmosis as a result of its membrane permeability. The ash content of the raw leaves of Talinum triangulare fell within the acceptable range of edible vegetables in Nigeria [14].The decrease in the ash content of the cooked vegetable, which is a reflection of its total mineral content, may suggest that the conventional method of cooking this vegetable decreases its mineral content.

One of the medicinal properties of Talinum triangulare is in the management of disease conditions such as: diabetes mellitus, stroke and obesity $[5,15]$.

Dietary fibre decreases the absorption of cholesterol from the gut and thus functions in the protection against cardiovascular disease, colorectal cancer and obesity. It also delays the digestion and conversion of starch to simple sugars, an important factor in the management of diabetes mellitus [16]. Thus, the increased fibre content of the cooked leaf of Talinum triangulare could be of benefit to people suffering from diabetes mellitus, obesity or cardiovascular diseases, justifying its usage in the traditional management of the aforementioned diseases.

Generally, vegetables are known to contain small quantities of lipids and the lipid content in the leaves of Talinum triangulare decreased with chosen method of cooking. This decrease in the lipid content of the vegetable that was subjected to cooking in water could be attributed to the fact that some of the lipids may have leached into the boiling water. 
The increased protein content of the cooked Talinum triangulare as observed in this study, suggests that cooking of this raw vegetable enhances the release of its nitrogen during acid digestion.

The decrease in carbohydrate content of the cooked form of Talinum triangulare could be attributed to some low molecular weight carbohydrates (monosaccharides and disaccharides) present in the vegetable that may have leached into the processing water $[17,18]$.

The energy value of the raw vegetable as obtained in this study was within the range reported by Chinma and Ignyor [19]. The results indicate that both the raw and cooked leaves forms of Talinum triangulare cannot be recommended solely to vegetarians because of the low energy content. Thus consumption of other food substances that are rich in energy content alongside the vegetable may be necessary.

The results obtained showed that Talinum triangulare is a rich source of some water soluble as well as fat soluble vitamins which was not surprising as most of these vitamins are abundant in plants as they are synthesized from plant tissues.

Riboflavin is involved in the regulatory functions of some hormones that are connected with carbohydrate metabolism. Niacin (Vitamin B3) is essential for the normal functioning of the skin, intestinal tract and the nervous system. Tocopherol as a lipophilic vitamin, is the most powerful antioxidant [20]. Tocopherol protects the red blood cell from hemolysis, boosts the immune response, reduces the risk of myocardial infarction by reducing the oxidation of LDL as well as acting as an anti-mutagen. It also functions synergistically with other antioxidants like vitamin $A$ and $C$ and selenium [21]. Vitamin $C$ functions as a water soluble antioxidant.

Although riboflavin and niacin are heat stable, the tocopherol, thiamin and vitamin $\mathrm{C}$ contents of some foods decrease with cooking and this could be the explanation for the decreased quantities of these vitamins (tocopherol, thiamin, vitamin C) in the cooked vegetable $[20,22]$. Our findings however, on tocopherols are in contrast to that of Simone et al [23] who reported increased release of tocopherols in Broccoli after heat treatment. The decrease in the levels of riboflavin and niacin in the cooked vegetable may be due to leaching of the cell content with cooking, as the method ruptures the cell wall of the vegetable. In addition, the lower percentage loss of tocopherol compared with the water soluble vitamins is attributed to the fact that the fat soluble vitamins ( $A$ and $E$ ) are said to be less heat labile than the water soluble vitamins [24].

The carotenoids have been shown by various researchers as anti-cancers agents. The loss of carotenoid contents in the cooked vegetable is attributed to the softening of the plant tissue leading to the release of the carotenoids [7]. In addition, the study showed that the conventional cooking method for Talinum triangulare retained the carotenoids better than vitamin $\mathrm{C}$ and this justifies the hydrophobic and hydrophilic nature of carotenoid and vitamin $\mathrm{C}$, respectively.

Flavonoids, alkaloids and tannins are polyphenolic compounds with antioxidant properties. The inhibition of the glycolytic activity of brush border enzymes by polyphenolic compounds seems to be one of the factors that stimulates hypoglycemic action in some medicinal plants [25]. In addition, flavonoids, as antioxidants may prevent the progressive impairment of pancreatic beta cell function due to oxidative stress, thereby reducing the occurrence of 
diabetes. Tannins inhibit the activities of digestive enzymes such as trypsin, chymotrypsin, amylase and lipase. The tannin-epigallo-catechin-3-gallate is known to possess hypoglycemic activity. Saponins on the other hand, have been associated with cholesterol lowering activities [25]. Although, the cooked leaves of the vegetable lost some of these polyphenolic compounds, however the residual polyphenolic compounds in the cooked leaves of Talinum triangulare were not significantly different $(P>.05)$ from that of the raw sample. This confers significant antioxidant potentials to both the raw and cooked samples of the vegetable. This finding may justify why Talinum triangulare is used in the traditional management of diabetes mellitus and obesity.

The amount of cyanide in plants are always taken into consideration when such plants are to be consumed since cyanogenic glucosides are present in most plants and the quantities available could make the plant to be either toxic, non-toxic or lethal when eaten bearing in mind that cyanide is an effective cytochrome oxidase inhibitor in the electron transport chain partway. The concentration of cyanide in the raw and cooked samples of the vegetable was lower than the lethal dose range of $50-300 \mathrm{mg} / \mathrm{kg}$ body weight $[26,27]$. Therefore, the leaves of Talinum triangulare are safe for consumption with respect to cyanide content.

Sterols are a subgroup of steroids with a hydroxyl group at the 3-position of the A-ring. They are amphipathic lipids synthesized from acetyl-coenzyme A via the HMG-CoA reductase pathway. Sterols of plants, known as Phytosterols, have been shown in clinical trials to block cholesterol absorption sites in the human intestine, thus helping to reduce cholesterol in humans [28]. In addition, they are currently approved by the U.S. Food and Drug Administration for use as food additives but in large quantities, they may inhibit the absorption of other important nutrients as well [29]. However, the range of sterols that was obtained in both the raw and cooked leaves of Talinum triangulare, was within the range $(0.01-10 \%)$ of sterols in plants.

The qualitative rapid thin layer chromatography screening for antioxidant activities of the methanolic/ethanolic extracts of both the raw and cooked samples of the vegetable was positive, as the colour of the DPPH changed from purple to yellowish spots, indicating the presence of antioxidant activities in both forms of the vegetable. However, the cooked leaves had lower antioxidant activity than the raw leaves of the vegetable and this may be due to the losses of antioxidant compounds such as: the lipohilic (tocopherol, $\beta$-carotene), hydrophilic (vitamin $\mathrm{C}$ and flavonoids during cooking) as well as polyphenolic constituents when the raw vegetable was cooked.

The higher scavenging activity of the raw leaves of Talinum triangulare than the cooked one on 2,2 diphenyl-1-picrylhydrazyl (DPPH) radical could be attributed to their Polyphenolic, $\beta$ carotene, vitamin $\mathrm{C}$ and tocopherol contents than in the cooked leaves.

Minerals, as inorganic elements, are divided into macro-minerals which are required in amounts $>100 \mathrm{mg} / \mathrm{d}$ and micro-minerals or trace elements which are required in amounts < $100 \mathrm{mg} / \mathrm{dl}$ [30]. They function as co-factors in enzyme catalyzed reactions, regulation of acidbase balance, nerve conduction, muscle irritability and structural elements of the body.

Calcium, Magnesium and Phosphorous fall under macro-nutrients or the principal mineral elements and they form important constituents of the bones and teeth. Calcium functions as calmodulin binding regulatory protein, and mediates the excitation and contraction of the muscle fibers. Magnesium functions as an activator of many ATP requiring enzymes such as: alkaline phosphatase, hexokinase, fructokinase, PFK, adenyl cyclase, etc, as well as 
playing a role in insulin sensitivity. Phosphorous functions in the production of high energy compounds such as: ATP, CTP, GTP, creatine phosphate, etc as well as phosphate buffer system in the blood.

Fe and $\mathrm{Zn}$ function as essential trace elements (micronutrients). Fe functions mainly in the transport of oxygen to the tissues, and its also involved in cellular respiration. It also influences glucose metabolism, insulin action as well as interfering with insulin inhibition of glucose production by the liver. $\mathrm{Zn}$ functions as an essential constituent of many enzymes such as: carbonic anhydrase, alkaline phosphatase. Its also concerned with the healing of wounds as well as playing a key role in the regulation of insulin production by pancreatic tissues and glucose utilization by muscles and fat cells. This study indicated that cooking the raw vegetable resulted in the loss of some quantities of these minerals which could be attributed to leaching into the cooking water rather than their destruction [31]. The results we obtained in this study with respect to the mineral elements investigated, are similar to previous reports of other researchers [15,32] on some other species of Nigerian vegetables. Chlorophylls are of great importance in plants because of their role in photosynthesis which plays a critical role in the survival of life on earth. The degree of greenness, due to chlorophyll content, is important in determining the final quality of green vegetables [33]. Chlorophyll and its derivatives exert beneficial effects such as anti-carcinogenic and antimutagenic activities [34]. Many green vegetables contain volatile acids that are partially given off during cooking. Covering the cooking vessel leads to the volatile acids being dissolved in the steam generated from condensation and this leads to a reduction of the $\mathrm{pH}$ of the cooking water. Chlorophyll is very sensitive to any $\mathrm{pH}$ below 7 and is converted to pheophytin. This could be one explanation for the reduced chlorophyll content of the cooked vegetable. In addition, Chlorophyll molecules which exist in the chloroplast as protein complexes are very unstable. Thus during cooking of the vegetable, the protein gets denatured with the corresponding release of the chlorophyll. This could account for the significant loss of this molecule in the cooked leaves of Talinum triangulare.

\section{CONCLUSION}

The study showed that Talinum triangulare possesses considerable amounts of proximates, phytochemicals, minerals, vitamins, chlorophyll and anti-oxidant activity. However, the vegetable is low in carbohydrate and energy value. The traditional method of cooking this vegetable results in insignificant loss of proximates, phytochemicals, $\mathrm{Ca}, \mathrm{Fe}, \mathrm{Zn}$, thiamin, riboflavin, niacin and tocopherol, but significant loss of vitamin $\mathrm{C}$, carotenoids, $\mathrm{Mg}, \mathrm{P}$, chlorophyll and antioxidant activity with a corresponding increase in moisture, proteins and crude fibre contents. Finally, the traditional method of cooking Talinum triangulare retains tocopherols better than vitamin C.

\section{CONSENT}

Not applicable.

\section{ETHICAL APPROVAL}

Not applicable. 


\section{ACKNOWLEDGEMENT}

We want to appreciate immensely, Mr Ikpeama of the Tissue culture Laboratory, National Root Crops Research Institute, Umudike, Nigeria for the technical assistance he rendered.

\section{COMPETING INTEREST}

Authors have declared that no conflict of interest.

\section{REFERENCES}

1. Martin FW, Ruberte-Meitner LS. Edible Leaves of the Tropic: Educational concerns for Hunger organization, INC: 1998;1-8.

2. Ezekwe MO, Besong SA, Igbokwe PE. Beneficial influence of purslane and waterleaf supplement to Humans. FASEB J. 2001;16:A639.

3. Oguntona T. Green Leafy Vegetables. In: Nutritional Quality of Plant Food, Osagie, A.U. and O.U. Eka (Eds.). Ambik Press: 120-133:1998.

4. Mensor LL, Fabio SM, Gildor GL, Alexander SR, Tereza CD, Cintia SC, Suzane GL. Screening of Brazilian plant extracts for antioxidant activity by the use of DPPH free radical methods. Phytother. Res. 2001;15:127-130.

5. Aja PM, Okaka ANC, Onu PN, Ibiam U, Urako AJ. Phytochemical composition of Talinum triangulare (Water Leaf) Leaves. Pak. J. Nutr. 2010;9:527-530.

6. Standard Operating Procedures (SOP). Chlorophyll determination; 1994;1-6.

7. Rodriguez-Amaya Delia B, Mieko Kimura. Harvest plus Handbook for Carotenoid Analysis. Harvest Plus Technical Monograph 2. Washington, DC and Cali: International Food Policy Research Institute (IFPRI) and International Center for Tropical Agriculture (CIAT); 2004;34-36.

8. Onwuka Gl. Food Analysis and Instrumentation. Theory and Practice. Napthali Prints. 2005;140-146.

9. Blois MS. Antioxidant determination by use of stable free radicals. Nature. 1985;29:1199-1200.

10. Association of Official Analytical Chemists. Official Methods of Analysis. W Horwitz (ed) 13th Edn. 1990;233-234.

11. Harbone JB. Comparative biochemistry of the flavonoids. New York Academic Press. 1973;221-222.

12. Okwu DE, Josiah C. Evaluation of the chemical composition of two Nigerian medicinal plants. African Journal of Biotechnology. 2006;5(4):357-361.

13. Tsen. An improved spectrophotometric method for the determination of tocopherols using 4,7 diphenyl-1, 10-phenanthroline. Annal Chem. 1961;33(7):849-851.

14. Lucas EO. The potential of leaf vegetable in Nigeria. Outlook on Agric. 1998;17(4):4-7.

15. Joshua ZP, Timothy AG, Suleiman MM. The effect of cooking time on the vitamin C, dietary fiber and mineral compositions of some local vegetables. Science World Journal. 2012;7(1):29-30.

16. Monago $\mathrm{C}$, Uwakwe A. Proximate composition and in vitro anti-sickling property of Nigeria cyperus esculentus (Tiger nut sedge). Trees Life J. 2009;4(2):1-6.

17. Lilian HMC. Food Chemistry: CBS Publishers, India: 2002;137.

18. FAO. Carbohydrates in Human Nutrition. FAO Document Repository. Agriculture and Consumer protection. 1998; Vol66.

Available: http://WWW.FAO.Org/docrep/W8079E/W8079E00.htm. 
19. Chinma CE, Igyor MA. Micronutrients and anti-nutritional contents of selected tropical vegetables grown in Southeast, Nigeria. Niger. Food J. 2007;25(1):111-116.

20. Vasundev V. Fundamentals of Biochemistry, Textbook of Biochemistry. $2^{\text {nd }}$ Edition. 2006;281-289.

21. Wagner KH, Kamal-Eldin A, Elmadfa I. Gamma-tocopherol-An Underestimated Vitamin? Ann Nutr Metab. 2004;48:169-188.

22. Deb AC. Concepts of Biochemistry, Theory and Practice. Revised Edition. Arunabha: Sen Publishers: 2004;132-137.

23. Simone B, Elmar S. Impact of different cooking methods on food quality: Retention of lipophilic vitamins in fresh and frozen vegetables. Journal of Food Engineering. 2006;77:327-333.

24. Beyza E, Akif O. The effect of cooking methods on mineral and vitamin contents of African catfish. Food Chemistry. 2009;115:419-422

25. Eleazu CO, Okafor PN. Antioxidant effect of unripe plantain (Musa paradisiacae) on oxidative stress in alloxan-induced diabetic rabbits. International Journal of Medicine and Biomedical Research. 2012;1(3):1-10.

26. Akiyama H, Toida T, Sakai S, Amakura Y, Kondo K, Sugita-Kunishi Y, Maitani T. Determination of cyanide and thiocyanate in Sugihirata Ke Mushroom using HPLC method with fluorimetric detection. J. Health Sci. 2006;52:73-77.

27. Bolhius GG. The toxicity of cassava roots. Netherlands J. of Agricultural Sci. 1954;2:176-185.

28. Fahy E, Subramaniam S, Brown HA. A comprehensive classification system for lipids. J. Lipid Res. 2005;46(5):839-61. doi:10.1194/jIr.E400004-JLR200. PMID 1572256.

29. Ostlund RE, Racette SB, Stenson WF. Inhibition of cholesterol absorption by phytosterol-replete wheat germ compared with phytosterol-depleted wheat germ". Am. J. Clin. Nutr. 2003;77(6):1385-9. PMID 12791614.

30. Robert KM, Darry KG, Peter AM. Harper's Biochemistry. $23^{\text {rd }}$ ed: Appleton and Lange, USA. 1993;573.

31. Severi SG, Bedogni A, Manzieri M, Poli M, Battistini N. Effects of cooking and storage methods on the micronutrient content of foods. Europeall Journal o/Callcer Prevellioll.1997;6(suppl 1):521-524.

32. Mepba HD, Eboh L, Banigo DEB. Effects of Processing Treatments on The Nutritive Composition and Consumer Acceptance of Some Nigerian Edible Leafy Vegetables. African Journal of Food Agriculture Nutrition and Development. 2007;7(1):1-18.

33. Nisha P, Singhal RS, Pandit AB. A study on the degradation kinetics of visual green colour in spinach (Spinacea oleracea L.) and the effect of salt therein. J. Food Eng. 2004;64(1):135-142. [doi:10.1016/j.jfoodeng.2003.09.021].

34. Turkmen N, Poyrazoglu ES, Sari F, Velioglu YS. Effects of cooking methods on chlorophylls, pheophytins and colour of selected green vegetables. Int. J. Food Sci. Technol. 2006;41(3):281-288. [doi:10.1111/j.1365-2621.2005.01061.x].

(c) 2013 Ogbonnaya and Chinedum; This is an Open Access article distributed under the terms of the Creative Commons Attribution License (http://creativecommons.org/licenses/by/3.0), which permits unrestricted use, distribution, and reproduction in any medium, provided the original work is properly cited. 